\title{
Metallic Fuel Fabrication Process Development in Remote Fuel Fabrication Mock-Up at KAERI
}

\author{
Kiho Kim (D), Sang-Gyu Park, Hoon Song, and Jeong-Yong Park \\ Korea Atomic Energy Research Institute, 111 Daedeok-daero 989beon-gil Yuseong-gu, Daejeon 34057, Republic of Korea \\ Correspondence should be addressed to Kiho Kim; khkim5@kaeri.re.kr
}

Received 4 August 2020; Accepted 3 December 2020; Published 15 December 2020

Academic Editor: Guglielmo Lomonaco

Copyright (c) 2020 Kiho Kim et al. This is an open access article distributed under the Creative Commons Attribution License, which permits unrestricted use, distribution, and reproduction in any medium, provided the original work is properly cited.

\begin{abstract}
This paper presents a remote testbed for metallic fuel fabrication using surrogates or depleted uranium. The testbed named "remote fuel fabrication mock-up (RFFM)" was created at the Korea Atomic Energy Research Institute and specifically designed to incorporate remote operation and maintenance. The subsystems of the RFFM are described, and test results regarding remotely conducted metallic fuel slug fabrication at the RFFM are also presented. After fabricating fuel slugs using copper ingots, their specifications and properties were analyzed and evaluated using chemical analysis, radiographic tests, and diameter and weight measurements. Analysis results showed that the fabricated metallic fuel slugs have an acceptance rate of more than $90 \%$ and a casting ratio (ratio of weight of injected metal to charged metal) of more than 0.7. Moreover, operations involving remote handling of in-cell equipment were also satisfactory.
\end{abstract}

\section{Introduction}

Spent nuclear fuel generated in nuclear power plants contains approximately $93 \%$ uranium, $6 \%$ fission products, and $1 \%$ transuranic elements (TRU). To improve the technical and economic feasibility of spent nuclear fuel, studies on dry-process recycling of spent nuclear fuel have been conducted to achieve reduced disposal space, reduced radiotoxicity, and increased uranium utilization. The Korea Atomic Energy Research Institute (KAERI) is developing three key technologies for future nuclear fuel cycles: pyroprocessing technology, metallic nuclear fuel technology, and prototype generation-IV sodium-cooled fast reactor (PGSFR) technology. Pyroprocessing [1] is an electrochemical process to refine nuclear materials from spent pressurized water reactor (PWR) fuels and involves extracting uranium and TRU ingots. Metallic nuclear fuel technology is employed to fabricate a mixture of these uranium and TRU ingots with $\mathrm{Zr}$ into metallic fuel slugs. Such U-TRU-Zr metallic fuel slugs are applicable as fuel material in PGSFRs [2]. Because highly-radioactive spent nuclear fuel is used in all these technologies, development involves remote fabrication in completely shielded facilities.
KAERI also constructed a pyroprocessing-integrated inactive demonstration facility (PRIDE) [3] to demonstrate engineering-scale-integrated pyroprocessing head-end, electrolytic reduction, electro-refining, electro-winning, and waste treatment techniques [1]. In the PRIDE facility, pyroprocessing experiments using uranium or surrogates are conducted via remote handling systems [4] in an inert atmosphere of argon gas to test and evaluate the integrated processes and their processing equipment in terms of remote operability and maintainability.

Metallic fuel is a promising fast reactor fuel because of its advantages of high thermal response, simple fabrication, enhanced reactor safety, and continued recyclability [5-7]. The fabrication technology of metallic fuel has been developed and upgraded over several decades with improvements made to meet the needs of cost-effectiveness, remote operability and maintainability, mass productivity, and reduced radioactive waste. Metallic fuels for the fast reactor EBR-I, in the early 1960s, were fabricated using rolling, swaging, wire drawing, coextrusion, and centrifugal casting. Additional casting methods for metallic fuel fabrication were the continuous, gravity, and injection casting. Among these, injection casting was known as the most efficient process for 
metallic fuel fabrication to meet the above needs [8]. A great number of metallic fuels for use as driver fuel for EBR-II were fabricated by injection casting [9-11]. Argonne National Laboratory (ANL) also demonstrated recycling of metallic fuel by using metallic fuel slugs, which were refabricated remotely using recovered radioactive uranium in a hot cell.

Manual fabrication of uranium or surrogate metallic fuel slugs has been conducted by injection casting of equipment at lab scale [12] or engineering scale [13] and by gravity casting of equipment at lab scale [14]. Such injection or gravity casting of equipment cannot be performed by remote operation in a shielded facility because parts are assembled all at once. Because of the integral structure of the casting equipment, these processes also cannot be performed or maintained remotely using in situ devices. And, because of the high radioactivity of TRU ingots, it is necessary to fabricate TRU metallic fuel slugs in a shielded cell. All operations and maintenance activities of the in-cell equipment for TRU metallic fuel slug fabrication must be conducted remotely because, once the cell is active, direct worker access to the in-cell equipment is not possible.

From the viewpoints of remote operation and maintenance, KAERI is using injection casting to develop related remote technology for metallic fuel slug fabrication for PGSFRs. This work includes modular design and manufacturing of processing equipment, development of remote handling devices and tools, and design and construction of mock-ups for integration of processing equipment and remote handling systems for fabrication of metallic fuel slugs. In this paper, we describe the development status of the abovementioned metallic fuel fabrication technology at KAERI. Using surrogates or depleted uranium, we designed and constructed a remote testbed for metallic fuel slug fabrication. The testbed, called the "remote fuel fabrication mock-up (RFFM)," was constructed at the Fuel and Material Facility of KAERI in 2018 and was specifically designed to incorporate remote operation and maintenance. Various slug fabrication tests using copper have been conducted remotely in the RFFM. RFFM subsystems and their components are described, and test results regarding metallic fuel slug fabrication conducted remotely in the RFFM are also presented.

\section{Remote Fuel Fabrication Mock-Up}

The RFFM is a testbed demonstrating the full spectrum of remotely operated metallic fuel slug fabrication processes. Figure 1 provides a full-scale graphical model of the RFFM; Figure 2 shows the constructed RFFM [15]. It can be seen that the RFFM mainly comprises two subsystems: a system for metallic fuel slug fabrication, located inside the cell, and a system for remote handling, located both inside and outside the cell. The former [16] uses injection casting to fabricate metallic fuel slugs, and comprises several components: an injection-casting furnace (ICF, 1), a high-frequency generator (2), a vacuum pump (3), an argon pressure tank (4), a filter device (5), a chiller (6), and a mold assembly (not shown) located inside a mold housing (7); the component numbers within the parentheses are indicated in Figures 1 and 2 .

To facilitate remote operation and maintenance when necessary, the ICF (1), the main component of the system, was designed and constructed in modules. It has a crucible melting capacity of $15 \mathrm{~kg}$ per batch. More detailed subcomponents are shown in Figures 3 and 4. The ICF consists of several modules to fabricate metallic fuel slugs: a base frame (1-a), a lower chamber (1-b) mounted on the base frame, an upper chamber (1-c), an upper chamber actuator (1-d) to move the upper chamber upwards and downwards, a mold assembly actuator (1-e) to move the mold assembly (not shown) installed in the upper chamber downwards and upwards before and after casting, respectively, and a left (1-f) and right (1-g) ring connector to tighten or loosen the upper and lower chambers (see Figure 3 ).

Figure 4 shows the subcomponents located inside the lower chamber, including a spiral-shaped induction coil (1h) and a furnace cap (1-i) to cover and open a top of crucible (not shown) loaded inside an induction coil. Several subcomponents of the injection-casting furnace such as the upper chamber, the motor-driven upper chamber actuator, the motor-driven mold assembly actuator, and the electric connections (not shown) were designed in modules for an ease of remote replacement when damaged. Figure 5 shows an example of the process of remotely removing a damaged induction coil from the interior of the lower chamber for exchange.

Utilities such as gas, electricity, and cooling water produced by a high-frequency generator, an argon pressure tank, and a chiller are supplied to the ICF for casting through specially designed connections, which can be connected or disconnected remotely for maintenance. The mold housing stores a mold assembly, which can hold a maximum of 78 molds. These molds are made of quartz and have lengths of $450 \mathrm{~mm}$, thicknesses of $0.1 \mathrm{~mm}$, and outer diameters of $5.7 \mathrm{~mm}$. The mold assembly with empty quartz molds is moved from the mold housing to the center of the interior bottom side of the upper chamber before casting; cast mold assemblies are moved back to the mold assembly housing. All equipment pertaining to the system for metallic fuel slug fabrication is located inside the cell and requires remote handling for operation, replacement, maintenance, and transportation.

The latter, system, for remote handling, enables operators to fabricate metallic fuel slugs remotely inside the RFFM cell. It comprises two pairs of master (8-m)-slave (8-s) manipulators (MSMs), one overhead crane (9), one viewing window (10), and other auxiliary tools such as a camera (11) and a display panel (11-a), a hanger (12), and an impactor (13); the component numbers within the parentheses are indicated in Figures 1 and 2. All of these remote handling devices are operated remotely. Each MSM (8-m and 8-s) has an effective handling capacity of $15 \mathrm{~kg}$ in any position within its workspace, and a maximum handling capacity of $25 \mathrm{~kg}$ for a short period. A two-ton overhead crane (9), mounted on tracks installed above the RFFM, provides remote handling capability over the entire RFFM site and is used to handle equipment inside the cell. A viewing window (10) 


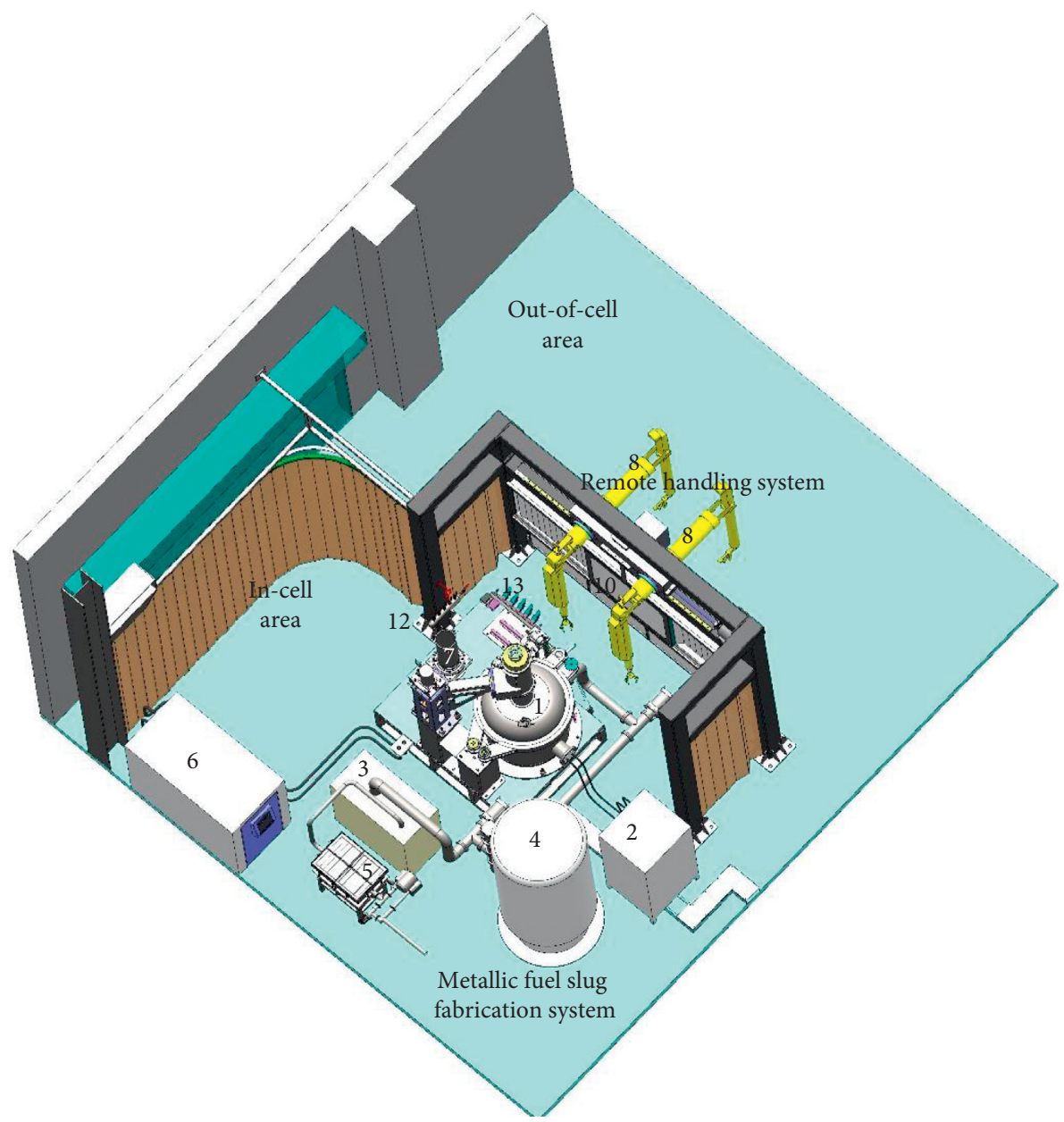

FIGURE 1: Full-scale graphical model of RFFM.

provides the operator with direct in-cell information or monitoring of in-cell situations during fuel slug fabrication operation. This window was constructed to be connected with two pairs of MSMs by a holder and can be moved in the left or right direction with respect to the front wall. Depending on the tasks required, the position of the window can also be varied with the movement of the operating position of the MSMs. This design provides operator with a more efficient means of operating the slug fabrication equipment located within the limited space of the cell. The camera (11) installed inside the cell is movable. It provides precise remote handling information regarding the slug fabrication equipment, assists MSMs in conducting remote tasks, and delivers additional in-cell information.

\section{Remote Fabrication Test}

3.1. Procedure. Tests for fabricating metallic fuel slugs remotely are conducted in the RFFM. Upon completion of each test, an operator outside the cell will grasp the handgrip of the master manipulator $(8-\mathrm{m})$ and control the slave manipulator ( $8-\mathrm{s})$ by moving the master manipulator $(8-\mathrm{m})$ (see Figure 2). The motions of the master manipulator, which is located outside the cell, are reproduced exactly by the slave manipulator located inside the cell. The operator can observe and monitor the in-cell movements or the situation of the slave manipulators through the viewing window (10) or display panel (11-a) located outside the cell. In-cell visual information appearing on the display panel is provided by a movable camera located inside the cell. Direct in-cell information is also provided through the viewing window located at the front wall of the cell. Operator controls the slave manipulator via the master manipulator to operate fabrication equipment or conduct the specific tasks required for slug fabrication.

A flowchart describing the steps of metallic fuel slug fabrication is provided in Figure 6. All work for metallic fuel slug fabrication, except steps 4 and 6 , is conducted in a remote manner. In step 4, casting is conducted electrically by manual operation via a control panel located outside the cell; no remote operation is necessary. Work in step 6 is not conducted remotely but manually, because equipment to remotely break the cast quartz molds and retrieve the cast metallic fuel slugs is under development. Remote activities of each step for metallic fuel slug fabrication, shown in Figure 6, are described in more detail in Table 1. In addition, the remote handling systems necessary to complete the tasks in each step are listed. The tools that are incorporated with the MSMs are impactors, hangers, pneumatic pedals, etc. 

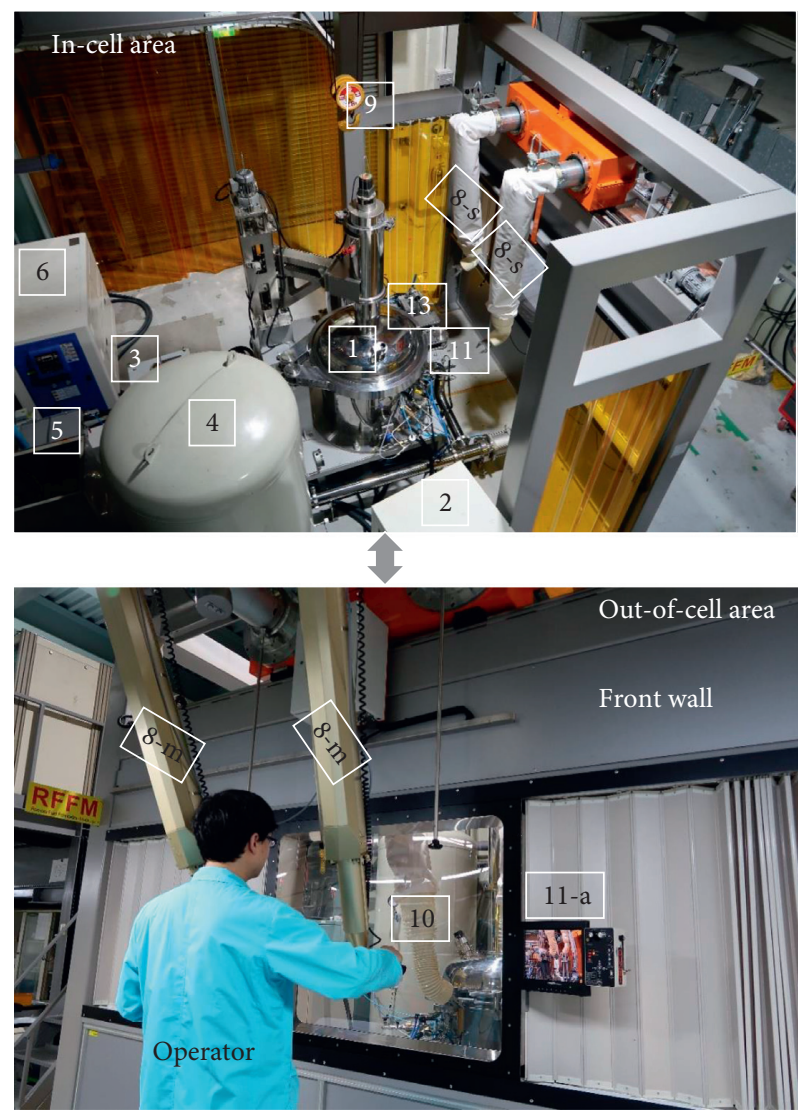

FIGURE 2: RFFM constructed at KAERI.

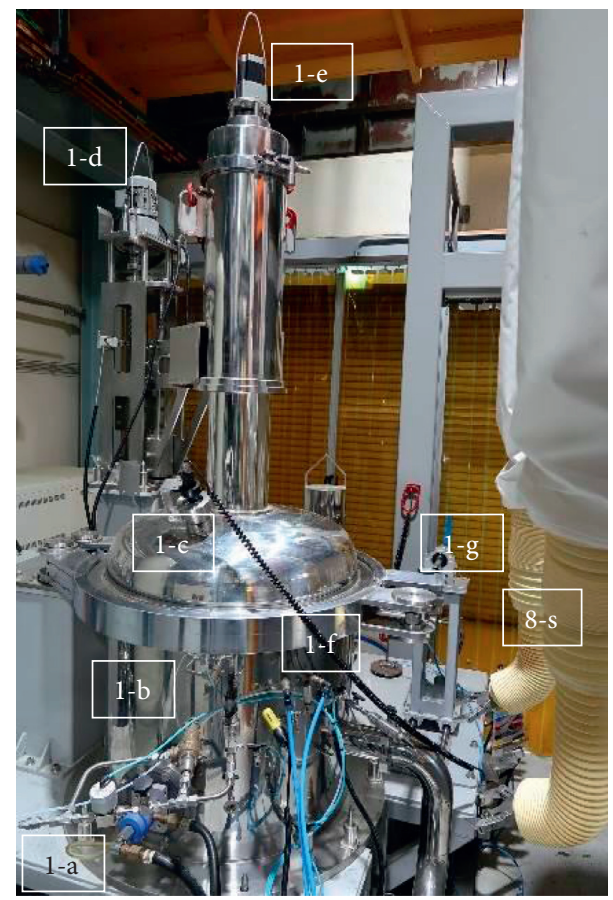

FIGURE 3: Subcomponents of induction-casting furnace.

As can be seen in Figure 6 and Table 1, the initial stage of the procedure for fabricating the metallic fuel slugs requires an operator to hold a crucible filled with input materials and

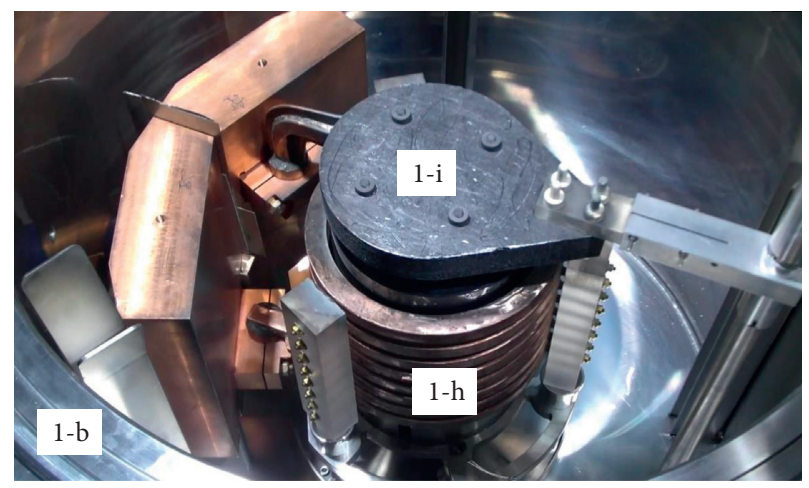

FIGURE 4: Induction coil and furnace cap located inside the lower chamber of injection-casting furnace.

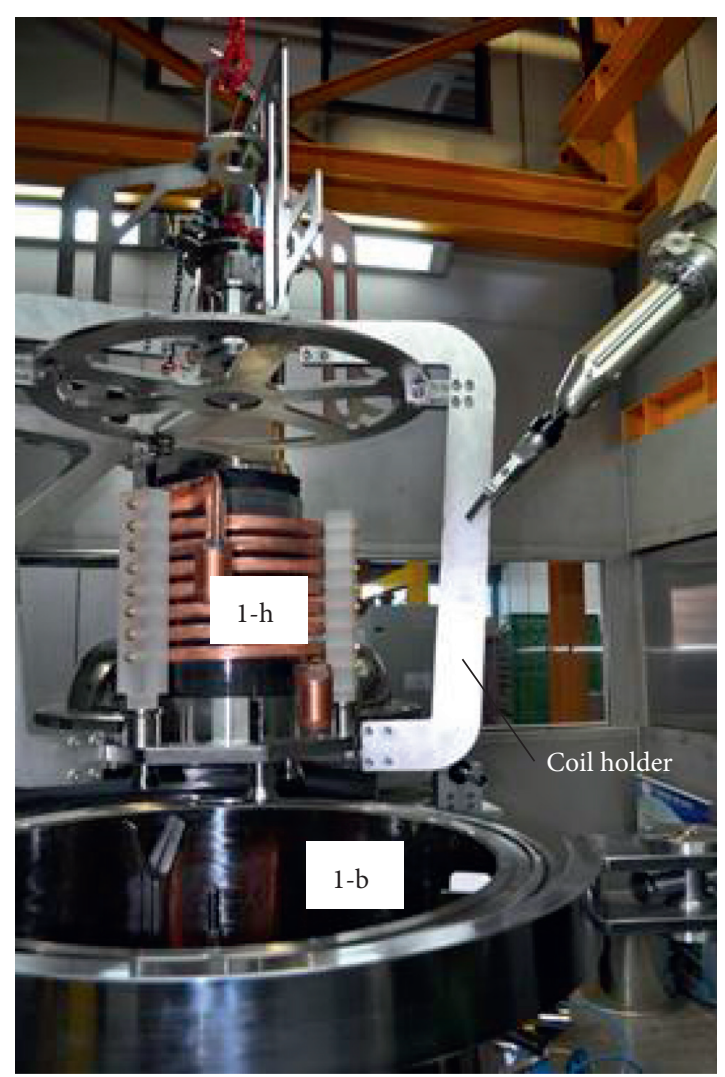

FIgURE 5: Example of remote maintenance pretest: removing a damaged induction coil from the interior of the lower chamber using a coil holder, a crane, and MSMs (booting removed) at mockup facility before installation in RFFM.

move the crucible to the ICF (step 1). This operation is realized using MSMs and the crane (see Figures 7 and 8). The cap of the crucible is removed after the crucible is loaded into the lower chamber of the ICF. A mold assembly equipped with empty quartz molds is then loaded into the upper chamber of the ICF (step 2, also see Figure 9). Upon closing the upper chamber and tightening the upper and lower chambers (step 3), the furnace is decompressed to a certain level and powered up to melt the input materials inside the crucible. 


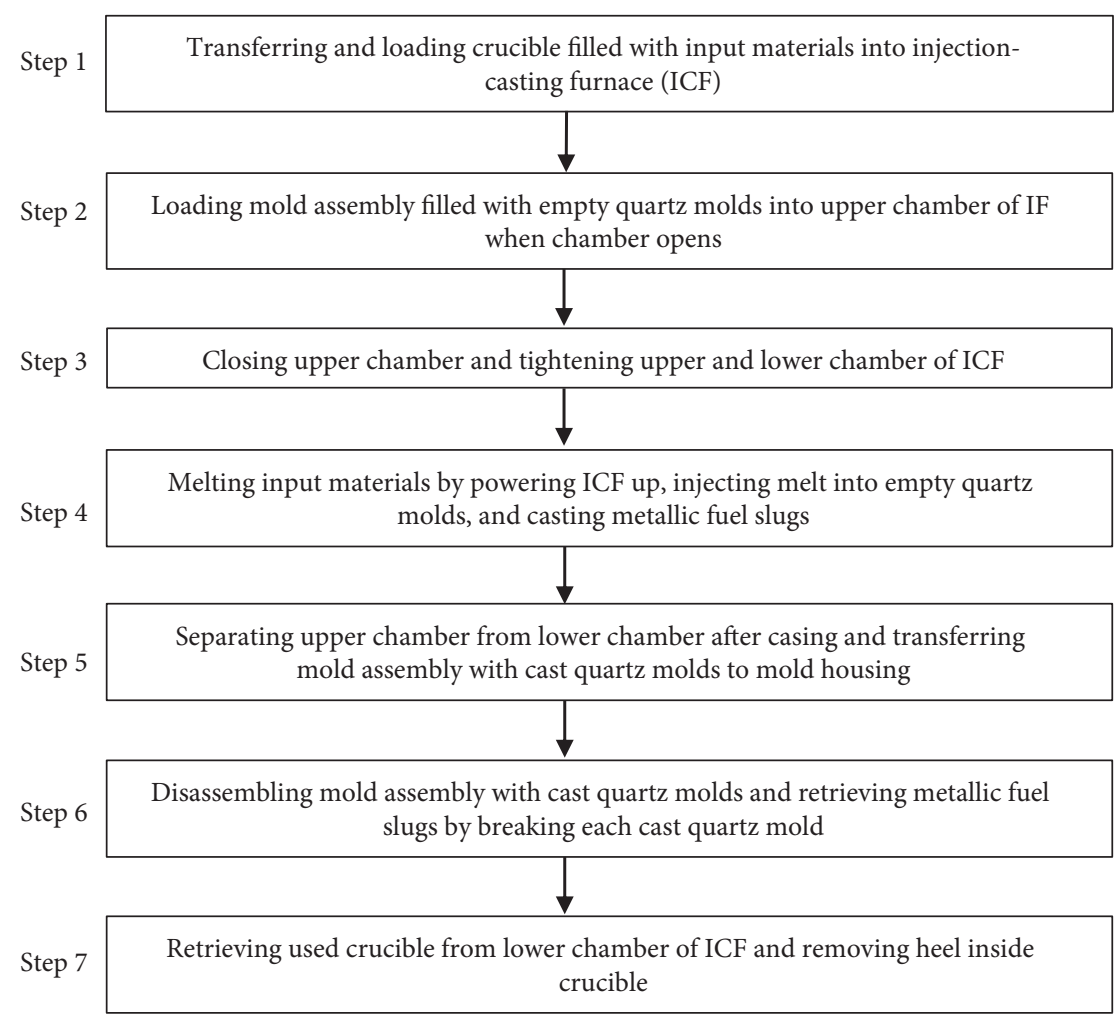

Figure 6: Procedure for metallic fuel slug fabrication.

Upon successfully melting input materials, the top of the crucible is opened by turning the furnace cap to the righthand side through remote operation; empty quartz molds are lowered and immersed into the molten solution inside the crucible; then, the molten solution is injected into the empty quartz molds to cast metallic fuel slugs. The quartz molds filled with molten solution are lifted up outside the crucible and cooled for several hours inside the chamber until molten solution solidifies (step 4). This task is conducted electronically by using the control panel to control the motors. Upon solidification of the molten solution inside the quartz molds, the upper chamber, with the mold assembly that holds cast quartz molds, is opened, lifted up, and transferred to the mold housing located outside the ICF (step 5). All of these procedures are conducted remotely using the remote handling devices installed in the RFFM, including MSMs, crane, camera, impactors, hangers, and pneumatic pedals. Next, quartz molds that contain cast metallic fuel slugs are separated from mold assembly. Metallic fuel slugs are retrieved by breaking the quartz molds and removing broken quartz (step 6). The utilized crucible located inside the induction coil of the lower chamber is covered, locked with the crucible cap, and transferred outside the ICF (step 7).

3.2. Tests and Results. As seen in both Figure 6 and Table 1, for the injection casting method, preliminary tests were manually conducted in the RFFM for metallic fuel slug fabrication using copper ingots before remote fabrication. No remote operation or remote handling was conducted.
These manual tests were performed to check the functional connections of the constructed metallic fuel slug fabrication system, to examine its performance and to evaluate the influence of the processing parameters necessary for casting the desired metallic fuel slug. These processing parameters included melting temperature, casting temperature, injection pressure, preheating time, and deposition time. Among these parameters, casting temperature, injection pressure, and deposition time of empty molds into melt solution were evaluated in terms of the length of the fabricated metallic fuel slugs and an empty quartz mold length of $450 \mathrm{~mm}$. Other parameters were kept constant for the tests, including melting temperature of $1,400^{\circ} \mathrm{C}$ and preheating time of two seconds. Evaluation of such parameters as the casting temperature, injection pressure, and deposition time was performed by varying the number of metallic fuel slugs to be fabricated per batch for each test, for example, by using 4,18 , 36,48 , and 78 metallic slugs per batch. Figure 10 shows the number of empty quartz molds and their locations in the mold assembly used for the tests. The black-colored solid circle indicates the location of the quartz mold installed on the mold assembly for casting. Each mold has a length of $450 \mathrm{~mm}$, thickness of $0.1 \mathrm{~mm}$, and outer diameter of $5.7 \mathrm{~mm}$. The maximum number of empty quartz molds that a mold assembly can hold is 78 . This means that the maximum number of metallic slugs that can be fabricated in one casting cycle is 78 .

Through the manual fabrication tests, the influences of the three processing parameters of casting temperature, injection pressure, and deposition time on the length of the 
TABLE 1: Remote operation tasks and remote handling systems for metallic fuel slug fabrication.

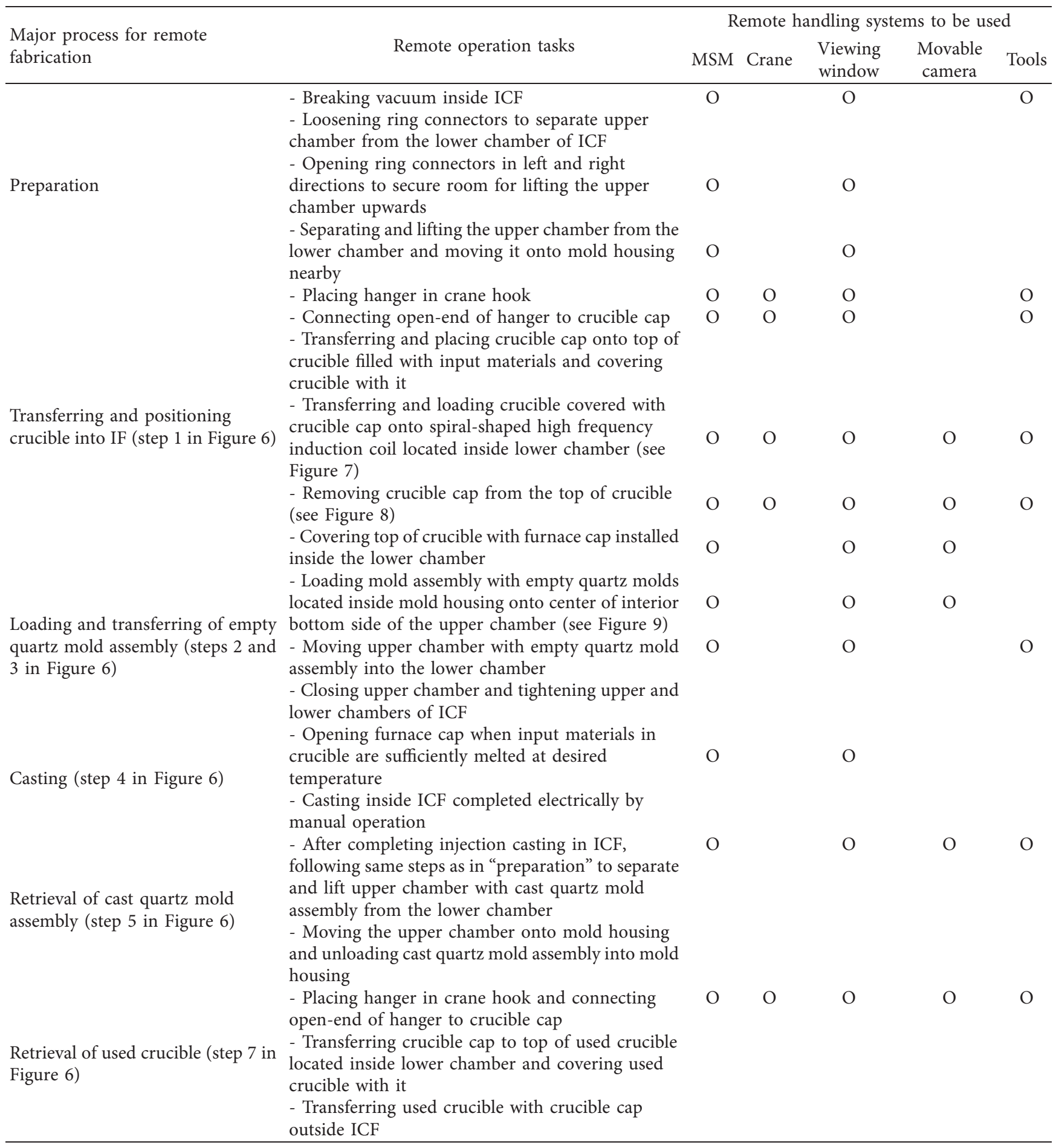

cast metallic fuel slugs were evaluated. Tests were conducted varying the above processing parameters in order to find optimal values for the better metallic fuel slugs. As the injection pressure increased, the length of cast metallic slugs increased. Test results showed that the length of the cast metallic fuel slugs approached approximately $440 \mathrm{~mm}$ as the empty mold length got closer to $450 \mathrm{~mm}$ under the following conditions: injection pressure of approximately $2.16 \mathrm{kgf} / \mathrm{cm}^{2}$, casting temperature of approximately $1,215^{\circ} \mathrm{C}$, and deposition time of three seconds. These parameter values were selected and used to fabricate the metallic fuel slugs remotely.

After the manual tests, with the above-selected parameter values, remote fabrication of metallic fuel slugs was conducted in the RFFM using copper ingots with a total weight of $10 \mathrm{~kg}$ per batch. Following the steps in Figure 6 and Table 1, a total of 78 metallic fuel slugs in one casting cycle 

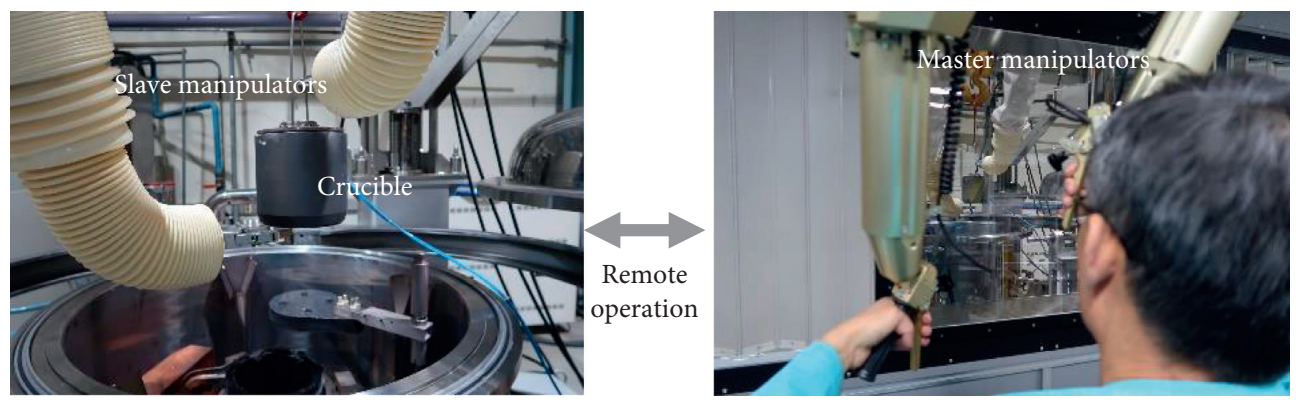

FIGURE 7: Moving crucible filled with copper ingots using MSMs and crane.

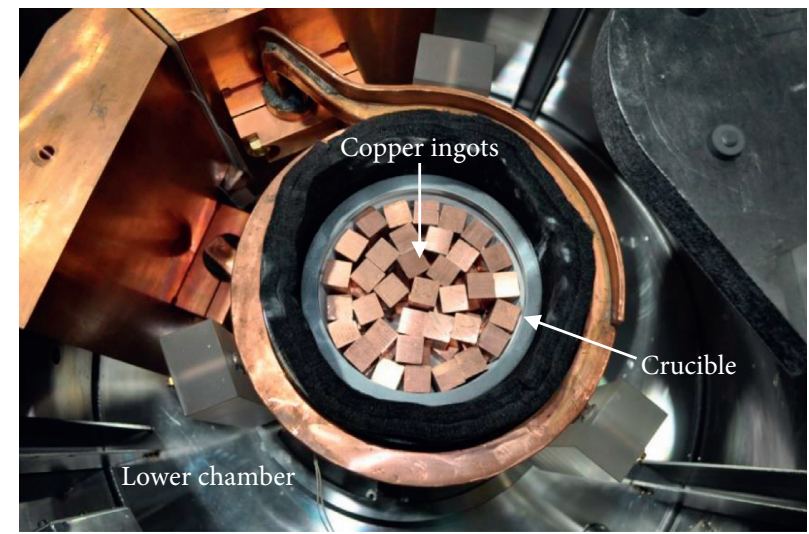

Figure 8: Crucible loaded inside the lower chamber of injection-casting furnace.

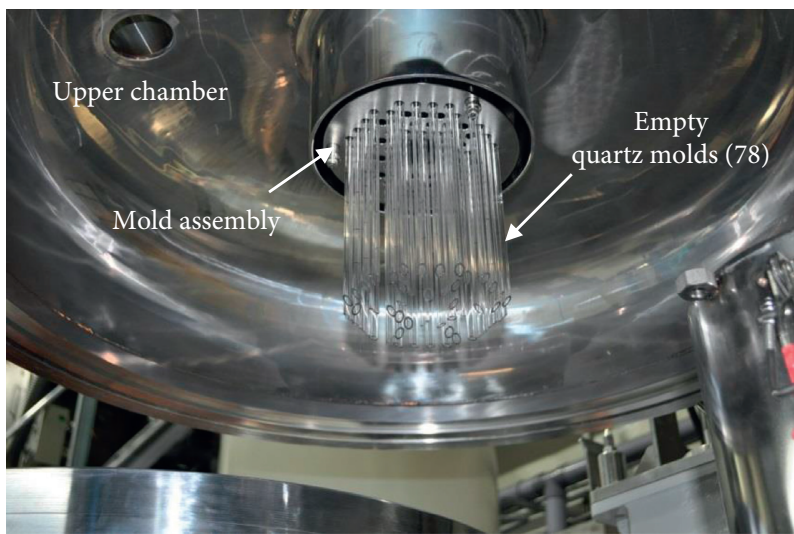

FIgURE 9: Mold assembly with 78 empty quartz molds loaded into center of interior bottom side of the upper chamber.

were fabricated remotely without directly accessing the incell equipment during fabrication. Relevant remote tasks for fabrication included the handling, transferring, and unloading of the crucible; the tightening, loosening, and movement of the upper chamber; and the handling of the mold assembly.

Upon completion of the casting, and after the upper chamber was separated from the lower chamber and lifted up, Figure 11 shows the mold assembly with quartz molds filled with cast copper metallic fuel slugs. Figure 12 shows the mold assembly holding cast 78 quartz molds separated from the upper chamber (a), 78 quartz molds with cast metallic fuel slugs inside separated from mold assembly (b), and cast metallic fuel slugs retrieved by breaking quartz molds (c). All fabrication processes except the tasks described in Figure 12 were conducted in a fully remote manner using remote handling devices installed in the RFFM.

Afterward, the specifications and properties of the remotely fabricated metallic fuel slugs were analyzed and evaluated by chemical analysis, radiographic tests, and diameter and weight measurements. Analysis results showed that the fabricated metallic fuel slugs have an acceptance rate of more than $90 \%$ and a casting ratio (ratio of weight of injected metal to charged metal) of more than 0.7. In addition, from the perspective of remote operation, the slug fabrication processes were performed satisfactorily through 

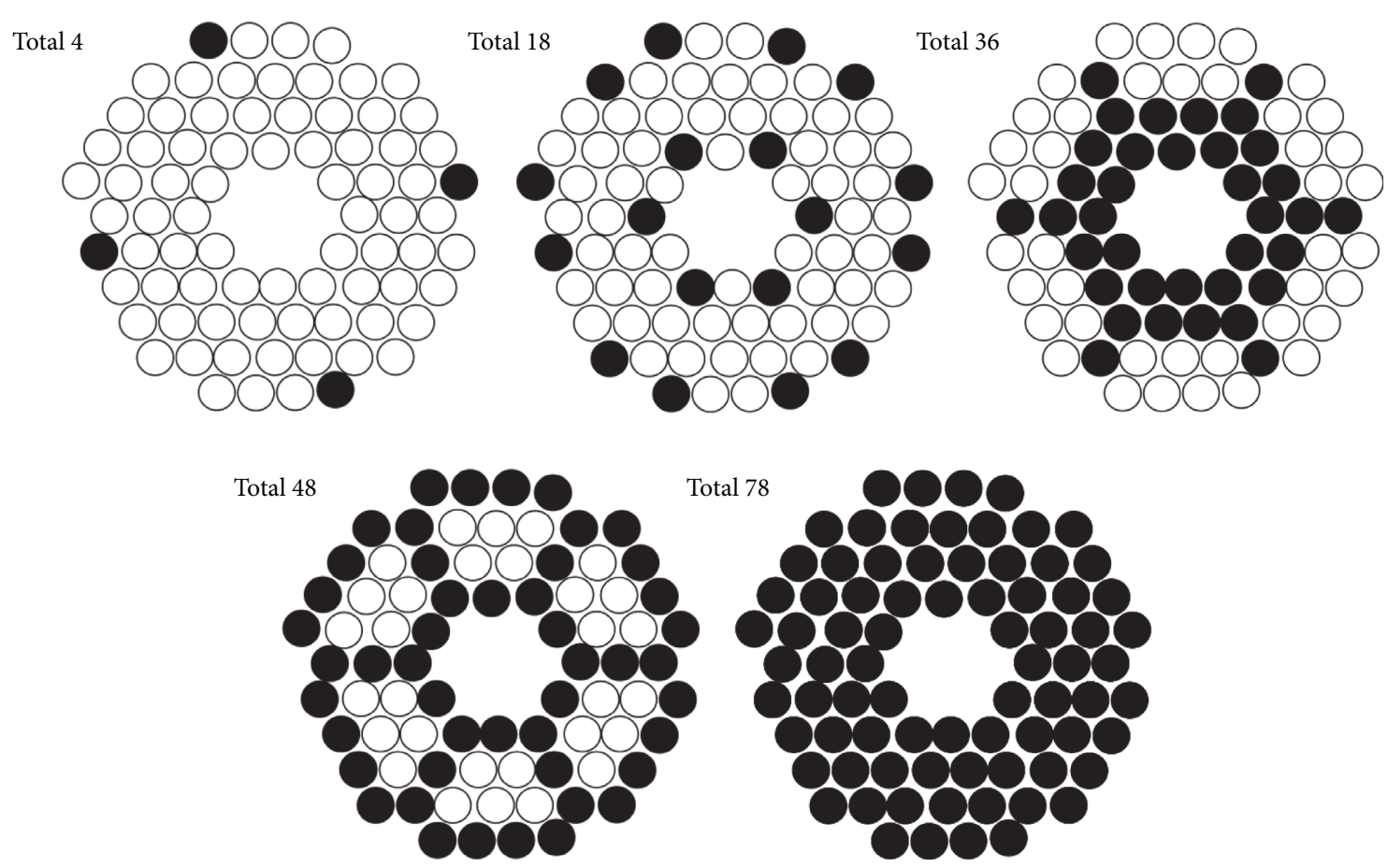

- Location of empty quartz mold mounted on the mold assembly

FIGURE 10: Number and location of empty quartz molds positioned in mold assembly before casting.

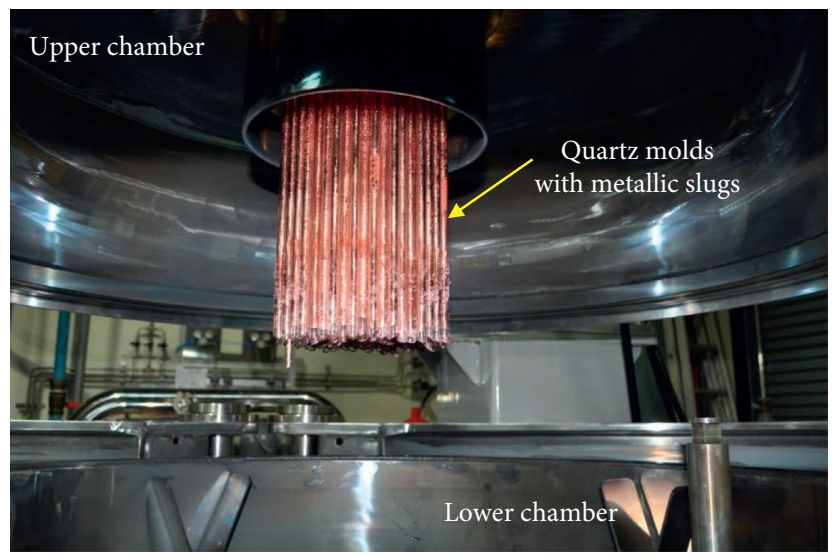

FIGURE 11: Quartz molds filled with metallic slugs after casting.

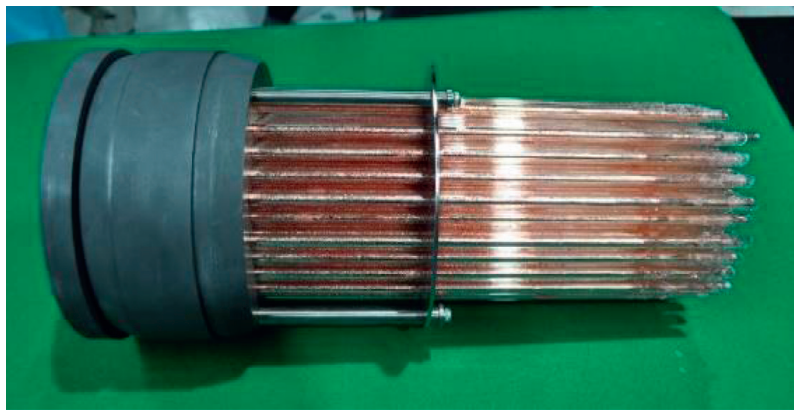

(a)

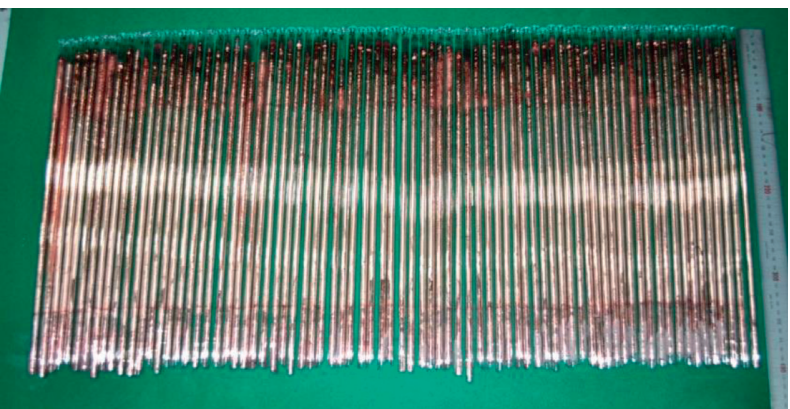

(b)

Figure 12: Continued. 


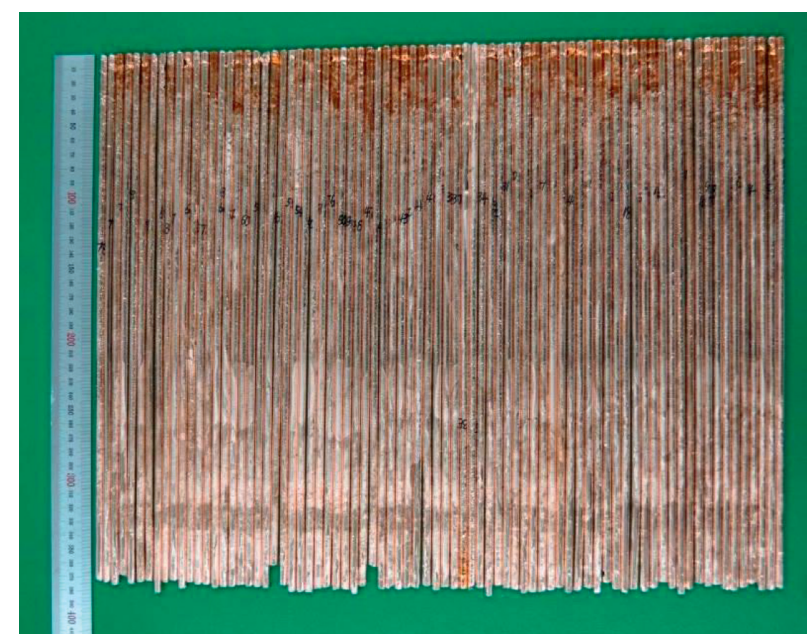

(c)

FIGURE 12: Copper metallic fuel slugs obtained through remote fabrication in RFFM. (a) Mold assembly holding 78 quartz molds filled with cast slugs. (b) 78 cast slug-filled quartz molds separated from mold assembly. (c) 78 cast slugs obtained by breaking quartz molds.

remote handling of the crucible and mold assembly (with empty molds or cast molds), remote handling of chamber tightening and loosening, and remote handling of other devices.

\section{Conclusions}

The significance of this application was in creating a remote testbed for metallic fuel slug fabrication named RFFM that incorporates remote operation and maintenance. Remote fabrication of metallic fuel slugs using copper ingots was satisfactorily conducted in the RFFM: a total of 78 metallic fuel slugs were fabricated in one casting cycle, and appropriate configurations of diameter and weight were obtained. The RFFM system also satisfied preliminary conditions of before and after fabrication for remote operation using remote handling systems, including opening and closing of the upper chamber of injection-casting furnace, transferring and positioning of crucible with input materials into the lower chamber of injection-casting furnace, loading empty quartz mold assembly into interior of the upper chamber and moving it into the lower chamber, and transfer and retrieval of used crucible. Similar additional remote fabrication tests using depleted uranium or surrogates in the RFFM must be conducted to determine proper processing parameters for engineering-scale metallic fuel slug fabrication. In addition, remote means of separating and retrieving cast molds from the mold assembly and of collecting metallic fuel slugs from the cast molds should be developed to demonstrate a full spectrum of integrated remote fabrication of metallic fuel slugs.

\section{Data Availability}

The data used to support the findings of this study wee obtained from reference [15] cited in the article.

\section{Conflicts of Interest}

The authors declare that they have no conflicts of interest.

\section{Acknowledgments}

This work was supported by Nuclear Research \& Development Program of the National Research Foundation of Korea funded by Ministry of Science and ICT (NRF2017M2A8A5014888).

\section{References}

[1] H. Lee, G.-I. Park, J.-W. Lee et al., "Current status of pyroprocessing development at KAERI," Science and Technology of Nuclear Installations, vol. 2013, pp. 1-11, Article ID 343492, 2013.

[2] C. B. Lee, J. S. Cheon, S. H. Kim, J. Y. Park, and H. C. Joo, "Metal fuel development and verification for prototype generation iv sodium-cooled fast reactor," Nuclear Engineering and Technology, vol. 48, pp. 1-13, 2016.

[3] K. Kim and I. Cho, "Pyroprocessing integrated inactive demonstration facility for pyroprocessing technology development," in Proceedings of the 19th Pacific Basin Nuclear Conference, pp. 1-10, British Columbia, Canada, August 2014.

[4] J. K. Lee, H. J. Lee, B. S. Park, and K. Kim, "Bridge-transported bilateral master-slave servo manipulator system for remote manipulation in spent nuclear fuel processing plant," Journal of Field Robotics, vol. 29, no. 1, pp. 138-160, 2012.

[5] L. C. Walters and J. H. Kittel, "Development and performance of metal fuel elements for fast breeder reactors," Nuclear Technology, vol. 48, no. 3, pp. 273-280, 1980.

[6] D. Mohr, L. K. Chang, E. E. Feldman, P. R. Betten, and H. P. Planchon, "Loss-of-primary-flow-without-scram tests: pretest predictions and preliminary results," Nuclear Engineering and Design, vol. 101, pp. 145-156, 1987.

[7] J. H. Kittel, B. R. T. Frost, J. P. Mustelier, K. Q. Bagley, G. C. Crittenden, and J. Van Dievoet, "History of fast reactor fuel development," Journal of Nuclear Materials, vol. 204, pp. 1-13, 1993. 
[8] L. C. Walters, B. R. Seidel, and J. H. Kittel, "Performance of metallic fuels and blankets in liquid-metal fast breeder reactors," Nuclear Technology, vol. 65, no. 2, pp. 179-231, 1984.

[9] C. E. Stevenson, The EBR-II Fuel Cycle Story, American Nuclear Society, La Grange Park, IL, USA, 1987.

[10] L. C. Walters, "Thirty years of fuels and materials information from EBR-II," Journal of Nuclear Materials, vol. 270, no. 1-2, pp. 39-48, 1999.

[11] D. E. Burkes, R. S. Fielding, D. L. Porter, D. C. Crawford, and M. K. Meyer, "A US perspective on fast reactor fuel fabrication technology and experience part I: metal fuels and assembly design," Journal of Nuclear Materials, vol. 389, no. 3, pp. 458-469, 2009.

[12] J.-H. Kim, J. W. Lee, K.-H. Kim, and J.-Y. Park, "Injection casting of $\mathrm{U}-\mathrm{Zr}$ and $\mathrm{U}-\mathrm{Zr}-\mathrm{RE}$ fuel slugs and their characterization," Journal of Nuclear Science and Technology, vol. 54, no. 6, pp. 648-654, 2017.

[13] M. Tokiwai, A. Kondo, R. Yuda et al., "Development of fabrication technology of metallic fuel by injection casting," Journal of Nuclear Science and Technology, vol. 39, no. sup3, pp. 910-912, 2002.

[14] K. Marsden, "Report on development concept for the advanced casting system in support of the deployment of a remotely operable research scale fuel fabrication facility for metal fuel," Technical Report INL/EXT-07-123469, Idaho National Laboratory, Idaho Hills, ID, USA, 2007.

[15] K. Kim, H. Song, Y. M. Woo, S. G. Park, S. W. Kuk, and J. Park, "Construction of remote fuel slug fabrication mockup,” Technical Report KAERI/TR-7874, Atomic Energy Research Institute, Daejeon, Korea, 2019.

[16] H. Song, J. Park, K. H. Kim et al., "Manufacturing and performance evaluation of casting equipment," Technical Report KAERI/TR-6786, Atomic Energy Research Institute, Daejeon, Korea, 2017. 